\title{
Zika Virus Infection during Pregnancy and Effects on Early Childhood Development, French Polynesia, 2013-2016
}

\author{
Lorenzo Subissi, Timothée Dub, Marianne Besnard, Teheipuaura Mariteragi-Helle, \\ Tuxuan Nhan, Delphine Lutringer-Magnin, Philippe Barboza, Céline Gurry, \\ Pauline Brindel, Eric J. Nilles, David Baud, Angela Merianos, Didier Musso, \\ Judith R. Glynn, Gilles Dupuis, Van-Mai Cao-Lormeau, ${ }^{1}$ Marine Giard, ${ }^{1}$ Henri-Pierre Mallet ${ }^{1}$
}

Congenital Zika virus syndrome consists of a large spectrum of neurologic abnormalities seen in infants infected with Zika virus in utero. However, little is known about the effects of Zika virus intrauterine infection on the neurocognitive development of children born without birth defects. Using a case-control study design, we investigated the temporal association of a cluster of congenital defects with Zika virus infection. In a nested study, we also assessed the early childhood development of children recruited in the initial study as controls who were born without known birth defects,. We found evidence for an association of congenital defects with both maternal Zika virus seropositivity (time of infection unknown) and symptomatic Zika virus infection during pregnancy. Although the early childhood development assessment found no excess burden of developmental delay associated with maternal Zika virus infection, larger, longer-term studies are needed.

$\mathrm{Z}$ ika virus is a mosquito-vectored flavivirus first isolated in 1947 in the Zika forest in Uganda (1). For the next 60 years, Zika virus was considered to cause sporadic and mild

Author affiliations: World Health Organization, Geneva, Switzerland (L. Subissi, P. Barboza, C. Gurry, P. Brindel); Institut Pasteur, Paris, France (T. Dub); French Polynesia Hospital Center, Pirae, French Polynesia (M. Besnard, D. Lutringer-Magnin); Institut Louis Malardé, Papeete, French Polynesia (T. Mariteragi-Helle, T. Nhan, D. Musso, V.-M. Cao-Lormeau); Brigham and Women's Hospital and Harvard Humanitarian Initiative, Boston, Massachusetts, USA (E.J. Nilles); World Health Organization, Manila, Philippines (E.J. Nilles, A. Merianos); University Hospital, Lausanne, Switzerland (D. Baud); Aix Marseille University, IRD, AP-HM, SSA, VITROME, IHU-Méditerranée Infection, Marseille, France (D. Musso); London School of Hygiene \& Tropical Medicine, London, UK (J.R. Glynn); University of Québec, Montreal, Québec, Canada (G. Dupuis); Centre de Liaison sur l'Intervention et la Prévention Psychosociales, Montreal (G. Dupuis); Bureau de Veille Sanitaire, Direction de la Santé, Papeete (M. Giard, H.-P. Mallet)

DOI: https://doi.org/10.3201/eid2410.172079 infection in humans (2). In 2007, Zika virus emerged in the Western Pacific island of Yap, Federated States of Micronesia (3). In 2013, Zika virus emerged in French Polynesia, causing a large outbreak $(>30,000$ clinical cases estimated during October 2013-April 2014) before spreading rapidly to other Pacific Islands (4-6). Zika virus emerged in Brazil in 2015 and spread to most of the Americas in 2016 (7).

Like some other members of the family Flaviviridae, such as West Nile virus and Japanese encephalitis virus, Zika virus is neurotropic (8). The link between Zika virus and neurologic disorders such as Guillain-Barré syndrome in adults and microcephaly in newborns is now established (9-15). Of 84 countries or territories with active autochthonous transmission of Zika virus (as of March 2017), 23 have reported an increase in incidence of Guillain-Barré syndrome, and 31 have reported patients with microcephaly, central nervous system (CNS) malformations, or both potentially associated with Zika virus infection (16). After the French Polynesia Zika virus outbreak, health authorities reported an unusual increase in microcephaly and other rare CNS abnormalities of unknown etiology, including corpus callosum or septal agenesis, spina bifida, and brainstem dysfunction (17).

Zika virus may be associated with multiple congenital abnormalities (18-20). The malformations and dysfunctions caused by Zika virus infection during pregnancy are known as congenital Zika syndrome (CZS), but the anatomic, functional, and neurocognitive impairments associated with in utero Zika virus infection have not been precisely defined (21). Characterizing the factors contributing to neurocognitive deficits in children born to mothers infected with Zika virus during pregnancy but without overt anatomic malformations, and quantifying the risk of neurocognitive dysfunction, may have major, substantive clinical and public health implications. 
We report 2 linked studies conducted in French Polynesia: a retrospective case-control study to determine whether the unusual cluster of CNS congenital defects during and after the Zika virus outbreak in French Polynesia was associated with maternal Zika virus infection, and a cross-sectional study to identify neurocognitive deficits in young children without known birth defects born to mothers who were pregnant during the outbreak. Both studies were powered on the case-control study.

\section{Methods}

\section{Study Design and Population}

\section{Case-Control Study}

The case-patient definition was any fetus or neonate with a CNS congenital defect of unexplained etiology and a maternal gestational period that overlapped the extended Zika virus circulation period (June 1, 2013-August 31, 2014) by $\geq 1$ weeks (17). Unexplained etiology meant that most commonly suspected etiologies (toxoplasmosis, other, rubella, cytomegalovirus, and herpes [TORCH] infections and genetics) were excluded. We identified cases and controls among fetuses and newborns from the Centre Hospitalier de Polynésie Française in Pirae, French Polynesia, where 60\% of all deliveries in this country occur. We identified eligible fetuses from pregnancy terminations using the medical records of the prenatal diagnosis center and eligible newborns from a previously reported case series of congenital cerebral malformations and dysfunctions (17) and from the in-hospital discharge records of the neonatology ward and the neonatal intensive care unit. We matched each case-patient to 5 controls by age of the mother at pregnancy $( \pm 5 \mathrm{y})$ and date of conception (date of mother's last prepregnancy menstrual period $\pm 14 \mathrm{~d}$ ). We selected the controls randomly from hospital birth records. For logistical reasons, only women residing in Tahiti or Moorea, the 2 most populated and accessible islands, were invited to participate as controls.

\section{Cross-Sectional Study}

Because a rate of $\approx 50 \%$ Zika virus seropositive mothers was expected in the control group of the case-control study, an additional cross-sectional study was designed to assess whether Zika virus infection in the mother was associated with delayed or abnormal early childhood development (ECD) in the child. Two nurses were trained to conduct anthropometric and neurocognitive testing. ECD was then compared between children with seropositive or seronegative mothers.

\section{Data Collection}

During January-August 2016, mothers of case-patients and controls completed a face-to-face questionnaire on social and economic characteristics, clinical data, and environmental factors, including exposure to chemicals (alcohol, tobacco, drugs, or deltamethrin pesticide spraying) during pregnancy. We retrieved information on seroconversion for Toxoplasma gondii and rubella virus during pregnancy from medical files; information on cytomegalovirus (CMV) seroconversion was available for case-patients only. We assessed exposure to deltamethrin by spatiotemporally linking outdoor spraying by the vector control teams with the mother's residence address during pregnancy. We stratified maternal socioeconomic status as low, medium, or high, adapting from the 4-factor Hollingshead scale (22). Gestational age was estimated by each mother's primary obstetrician, using last menstrual period and first-trimester ultrasound measurements for each mother.

\section{Laboratory Testing}

We detected anti-Zika virus and anti-dengue virus (DENV) neutralizing antibodies in serum from mothers of the case-patients and the controls by using seroneutralization tests, as previously described $(9,23)$. We incubated serial 2-fold dilutions (from 1:10 to 1:1,280) of each serum sample, previously heat inactivated, for $1 \mathrm{~h}$ with strains of Zika virus, DENV-1, DENV-2, DENV-3, or DENV-4. We then inoculated the serum-virus mixtures onto Vero cells and incubated then for 5-7 d. We used ELISA to show the presence of nonneutralized replicative virus in inoculated cells; the reciprocal serum dilution corresponding to the last well showing neutralization activity was the $50 \%$ neutralization antibody titer for that serum sample $(23,24)$. We determined Zika virus infection in mothers by detection of anti-Zika virus neutralizing antibodies (NAb) in serum collected 20-35 months after the expected beginning date of pregnancy. We defined mothers for whom the anti-Zika virus NAb titer was $\geq 20$ as seropositive and those with a titer $<20$ as seronegative.

\section{Assessment of Physical and Developmental Status of Children}

We used 4 anthropometric indicators for children's developmental status: weight for age, height for age, weight for height, and head circumference for age. We calculated $\mathrm{Z}$ scores (number of SDs of a value above or below the mean) using WHO Anthro software (25). We calculated birth anthropometric indicators ( $\mathrm{Z}$ scores for weight, height, and head circumference) using INTERGROWTH-21st project software (26). We used the French version of the Child Development Assessment Scale, kindly provided by the Centre for Liaison on Intervention and Prevention in the Psychosocial Area, Canada (http://www.ged-cdas.ca), to assess ECD. The Child Development Assessment Scale, which is available in French and is well correlated with the Bayley scale 3rd edition (27), consists of questions and 
observations adapted to children $0-5$ years of age and has been validated for use by nonspecialized health or education professionals (Vézina N. Elaboration and validation of the Child Development Assessment Scale, 0-5 years [thesis]. Québec City (QC, Canada): Université du Québec; 2005). The scale is divided into 3 domains: socioemotional; cognitive, including language; and motor. In each domain, children are classified as adequate (no development issues), question (development to be monitored), or problem (specialized pediatric testing required).

\section{Exposures, Outcomes, and Statistical Analysis}

We used 2 measures of exposure: maternal Zika virus seropositivity, a binary variable (yes/no) based on serology results; and reported Zika virus infection, a categorical variable, which used information reported by the mothers (Zika-like illness during or outside pregnancy), associated with serology results, and divided into symptomatic infection during pregnancy; asymptomatic infection, timing unknown; and no infection (seronegative mothers) and symptomatic infection when not pregnant. Zika-like illness corresponded to a clinical diagnosis of Zika virus disease or a recalled infectious episode characterized by rash, fever, or both associated with $\geq 2$ of the following symptoms: conjunctivitis, arthralgia, myalgia, or limb edema.

\section{Case-Control Study}

We performed a conditional logistic regression analysis to assess whether CNS congenital defect was associated with the 2 measures of exposure: maternal Zika virus seropositivity and reported Zika virus infection. We conducted a univariate analysis using all identified potential maternal risk factors and confounders (reported chikungunya infection, use of medical or recreational drugs, exposure to deltamethrin during pregnancy, age, socioeconomic status, history of miscarriage and/or termination of pregnancy), as well as parity and history of congenital defects in the family. Variables at $\mathrm{p}<0.2$ in the univariate analysis were further tested by multivariate conditional logistic regression and were retained in the final model if $\mathrm{p}<0.1$. When data sparsity did not allow adjustment for more variables, we retained only those at $\mathrm{p}<0.05$; we grouped maternal middle and high socioeconomic status categories together and compared them with low socioeconomic status. We used a Wilcoxon signed-rank test to compare means between cases and controls and Pearson $\chi^{2}$ test to compare categorical variables. We estimated the association between CNS congenital defects and maternal Zika virus infection by matched crude and adjusted odds ratios (ORs) with 95\% CIs. We maximized the study power for the case-control study, for which we aimed to include all eligible cases $(\mathrm{n}=$ 25 ), and we chose a control-case ratio of 5:1 to have $98.5 \%$ power to detect a bilateral $(\alpha=5 \%)$ significant difference, assuming $50 \%$ of controls (28) and $\geq 90 \%$ of cases (9) were seropositive for Zika virus. The case-control study protocol was approved by the French Polynesia Ethics Committee on February 2, 2016.

\section{Cross-Sectional Study}

The main outcome was a binary variable derived from the results of the Child Development Assessment Scale (no abnormal development vs. abnormal development). We performed a multivariate logistic regression analysis to assess the associations of ECD with maternal Zika virus seropositivity and reported Zika virus infection. We used the same method as described in the preceding section, with breastfeeding as an additional risk factor/confounder. We performed statistical analyses using Stata version 13.0 (StataCorp LLC, College Station, TX, USA). For the comparison between the French-speaking Canadian children $(n=269)$ and the sample of our cross-sectional study $(\mathrm{n}=107)$, we had a power of $80 \%$ to detect an effect size $d=0.32$ at $\alpha=$ 0.05 . The observed effect size (Cohen $d$ ) for the cognitive domain is 0.31 , and 0.2 for the motor dimension. For the affective dimension, the effect size ( $\phi$ coefficient) is 0.03 .

The cross-sectional study on ECD among controls was approved on June 3, 2016. We obtained written informed consent from all mothers.

\section{Results}

\section{Case-Control Study}

We identified 26 case-patients; 1 case-patient was later found to have a congenital defect with genetic etiology and thus was no longer eligible and was excluded from the analysis, along with the related 5 controls. The mother of 1 child with microcephaly, already described by Besnard et al. (17), as well as the mothers of 2 newborns retrospectively identified with other CNS abnormalities, declined to participate in the study. Another child's mother was lost to follow-up (Figure 1). Thus, a total of 21 case-patients ( $84 \%$ of those invited) and 102 controls (94\%) were enrolled in the casecontrol study.

We recruited 5 controls per case-patient for all but 2 case-patients; because of the tight matching and the lack of suitable controls, 1 case-patient had 4 matched controls and 1 case-patient had 3 . All controls and 17 case-patients were from Tahiti or Moorea (Figure 2).

Of the 21 case-patients, 7 had microcephaly, 5 had brainstem dysfunction of the neonate characterized by an inability to suck and swallow, and 9 had other CNS congenital defects (Table 1). Moreover, 6 had ventriculomegaly and 3 had arthrogryposis. Several case-patients had $\geq 1$ CNS abnormality. For 10 case-patients, pregnancy resulted in termination; of the remaining 11 newborns, 7 were still alive as of July 2017 (Table 1). Seven of the 11 newborns 


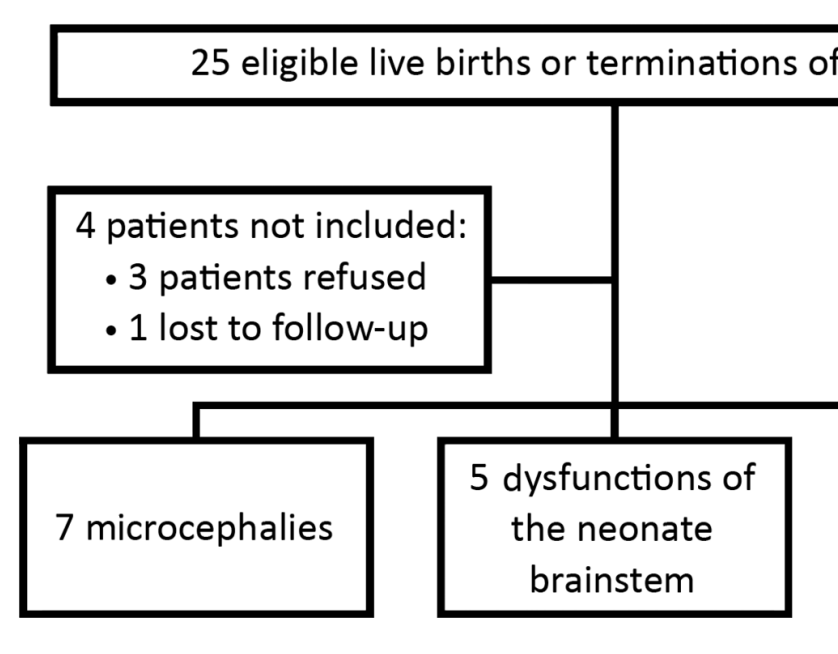

had complete imaging, ophthalmoscopy, evoked otoacoustic emissions, and neuroclinical follow-up.

Maternal toxoplasma serology was positive for $48 \%$ $(10 / 21)$ of the case-patients and $60 \%(61 / 102)$ of the controls; seroconversion occurred during pregnancy for 1 control. Rubella serology was positive for $81 \%(17 / 21)$ of the case-patients and 94\% (96/102) of the controls; no seroconversion occurred in any group. We performed maternal CMV serologic testing for $86 \%(18 / 21)$ of the case-patients: 2 were positive without signs of recent seroconversion, but further testing for CMV in amniotic fluid was negative (17). All study participants were seronegative for Treponema
Figure 1. Flowchart for the recruitment of eligible cases for study of Zika virus infection during pregnancy and effects on early childhood development, French Polynesia, 2013-2016.

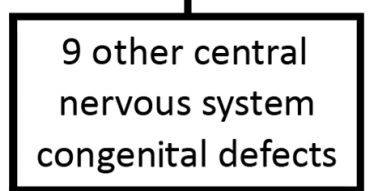

pallidum. The mother of 1 case-patient was known to be seropositive for HIV before the start of the pregnancy.

The gestational periods of fetuses and infants enrolled in the study started during June 2013-August 2014, and the infants were born during February 2014-May 2015. Median maternal age at conception was 27 years for case-patients and 28 years for controls. Case-patients and controls did not differ significantly in terms of fetal gender, ethnicity, and maternal socioeconomic status. Excluding the cases that ended in termination of pregnancy, gestational age at birth did not differ significantly between case-patients and controls (Table 2).

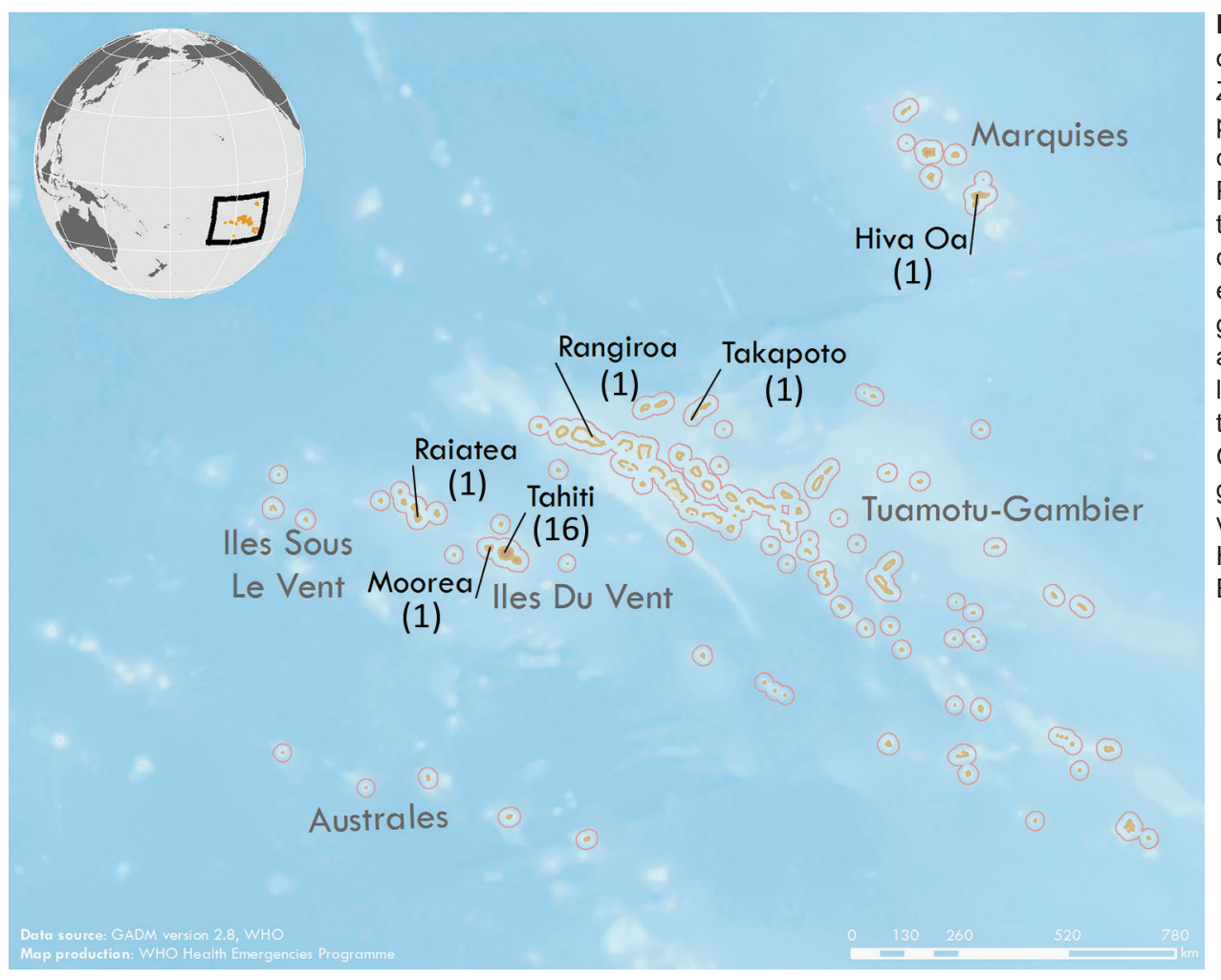

Figure 2. Geographic distribution of eligible cases for study of Zika virus infection during pregnancy and effects on early childhood development, French Polynesia, 2013-2016. Black text indicates islands with $\geq 1$ case (number of cases from each island is in parentheses); gray text indicates names of archipelagoes. Inset shows the location of French Polynesia in the Pacific Ocean. Data source: GADM version 2.8 (https:// gadm.org/download_country_ v2.html). Map production: World Health Organization Health Emergencies Programme. 
Table 1. Main and secondary diagnoses for 21 case-patients recruited in case-control study of Zika virus infection during pregnancy and effects on early childhood development, French Polynesia, 2013-2016

\begin{tabular}{|c|c|c|c|c|}
\hline Diagnoses & No. $(\%)$ & $\begin{array}{l}\text { Pregnancy } \\
\text { termination }\end{array}$ & Live births & $\begin{array}{c}\text { Child alive, }{ }^{*} \\
n=7\end{array}$ \\
\hline \multicolumn{5}{|l|}{ Main diagnoses } \\
\hline Microcephaly & $7(33)$ & 4 & 3 & 1 \\
\hline Brainstem dysfunction of the neonate & $5(24)$ & 0 & 5 & 3 \\
\hline Other CNS congenital defects & $9(43)$ & 6 & 3 & 3 \\
\hline Septal and/or corpus callosum agenesis & $3(14)$ & 1 & 2 & 2 \\
\hline Intraventricular hemorrhage & $1(5)$ & 0 & 1 & 1 \\
\hline Cerebral hemorrhage and placental calcifications & $1(5)$ & 1 & 1 & 0 \\
\hline Polymalformative syndrome & $2(10)$ & 2 & 0 & 0 \\
\hline Complete or sacral spina bifida & $2(10)$ & 2 & 0 & 0 \\
\hline \multicolumn{5}{|l|}{ Secondary diagnoses } \\
\hline Ventriculomegaly & $6(29)$ & 4 & 2 & 2 \\
\hline Arthrogryposis & $3(14)$ & 3 & 0 & 0 \\
\hline
\end{tabular}

Maternal Zika virus seroprevalence was $95 \%$ among case-patients and $76 \%$ among controls $(\mathrm{p}=0.07)$. We classified mothers of $38 \%$ of case-patients and $17 \%$ of controls as having had symptomatic Zika virus infection during pregnancy and mothers of $57 \%$ of case-patients and $60 \%$ of controls as having had asymptomatic infection (timing unknown, $\mathrm{p}=0.07$; Table 3 ). Of mothers who reported symptomatic Zika virus infection during pregnancy, for case-patients, $88 \%(7 / 8)$ reported it in the first trimester and $12 \%(1 / 8)$ in the second trimester, whereas for controls, $71 \%(12 / 17)$ reported it in the first trimester and 29\% (5/17) in the second or third trimester. Compared with those with no evidence of Zika virus infection during pregnancy, the matched crude OR for CNS congenital defects and maternal Zika virus seropositivity was 6.02 , and for CNS congenital defects and symptomatic Zika virus infection during pregnancy, the matched crude OR was 6.79. After adjustment for maternal socioeconomic status, these ORs were 7.07 for the first group (95\% CI $0.86-58.3$; likelihood ratio test $p=0.02$ ), and 7.19 for the second (95\% CI 1.39-37.2; likelihood ratio test $p=0.04)$. Further adjustment for other potential confounders made no difference to the results. Before and after adjustment for confounders, asymptomatic Zika virus infection (timing unknown) was not associated with CNS congenital defects (Table 3 ).

\section{Cross-Sectional Study of Early Childhood Development}

More than 1.5 years after the end of the Zika virus outbreak, during June-August 2016, we enrolled 107 children (median age 23 months) in a cross-sectional study and assessed them using the Childhood Development Assessment Scale. Of these children, 44 (41\%) were girls, 17 (16\%) were born prematurely, and $12(11 \%)$ were classified as having low birthweight $(<2,500 \mathrm{~g})$. Except for 1 low birth length baby, anthropometry at birth was within reference range; at the time of evaluation, none of the children was underweight, had low length for age, had low weight for length, or had microcephaly (online Technical Appendix Table 1, https:// wwwnc.cdc.gov/EID/article/24/10/17-2079-Techapp1.pdf).

We noted evidence for a difference between mean scores of the study participants and the reference population (French-speaking Canadian children) only for the cognitive domain $(\mathrm{p}=0.001)$ (online Technical Appendix Table 2). Neurocognitive testing using the Childhood Development Assessment Scale was normal for $93 \%$ of the children in the socioemotional domain, $64 \%$ in the cognitive domain, and $76 \%$ in the motor domain (online Technical Appendix Tables 3, 4). We found no evidence for a detrimental effect of maternal Zika virus seropositivity or reported Zika virus infection on ECD in children born without birth defects (Table 4). The weak univariate association of deltamethrin exposure during pregnancy with ECD delays was not significant after adjustment for confounders. Low maternal socioeconomic status (adjusted odds ratio [aOR] 5.28, 95\% CI 1.96-14.2) and not breast-feeding (aOR 4.00, 95\% CI 1.06-15.1) were associated with abnormal ECD.

\section{Discussion}

We report a case-control study assessing the role of Zika virus infection in CNS malformations, including, but not limited to, microcephaly, in newborns and fetuses whose gestation occurred during the Zika virus outbreak in French Polynesia during 2013-2014. We also report a populationbased developmental assessment of children born without birth defects after a Zika virus outbreak.

At the time of the outbreak in French Polynesia, risks associated with reported Zika virus infection were unknown. Four years later, 1 case-control study from Brazil provided evidence that Zika virus infection during pregnancy is associated with microcephaly, and a few cohort studies described Zika virus-associated adverse pregnancy outcomes $(11,14,18)$. Given widespread Zika virus transmission in the Western Hemisphere, clarifying the full spectrum of CZS is a critical public health priority. We conducted our study as part of the World Health Organization (WHO) effort in leading a multicountry 
Table 2. Characteristics and comparison of case-patients and controls in study of Zika virus infection during pregnancy and early childhood development, French Polynesia, 2013-2016*

\begin{tabular}{|c|c|c|c|}
\hline Characteristics & Cases, $n=21$ & Controls, $\mathrm{n}=102$ & $\mathrm{p}$ value \\
\hline Mother's age at pregnancy, median (IQR) & $26.8(22.1-35.7)$ & $27.8(22.2-33.7)$ & NA \\
\hline $15-24$ & $8(38)$ & $37(36)$ & NA \\
\hline $25-34$ & $7(33)$ & $43(42)$ & NA \\
\hline$>35$ & $6(29)$ & $22(22)$ & NA \\
\hline Estimated pregnancy start date, median (IQR) & $\begin{array}{c}2013 \text { Dec } 11 \\
(2013 \text { Oct } 23-2014 \text { May 9) }\end{array}$ & $\begin{array}{c}2013 \text { Dec } 8 \\
(2013 \text { Oct } 16-2014 \text { May } 16)\end{array}$ & \\
\hline January-September 2013 & $4(19)$ & $19(19)$ & NA \\
\hline October 2013-December 2014 & $9(43)$ & $43(42)$ & \\
\hline January-April 2014 & $2(9)$ & $10(10)$ & \\
\hline May-August 2014 & $6(29)$ & $30(29)$ & \\
\hline \multicolumn{4}{|l|}{ Maternal socioeconomic status } \\
\hline Low & $9(43)$ & $34(34)$ & 0.52 \\
\hline Middle & $4(19)$ & $31(31)$ & \\
\hline High & $8(38)$ & $36(36)$ & \\
\hline Child's birthweight, $\mathrm{g}$ & $\mathrm{n}=11$ & $\mathrm{n}=100$ & \\
\hline$<1,500$ & 0 & $2(2)$ & \\
\hline $1,500-2,500$ & $3(27)$ & $9(9)$ & \\
\hline$>2,500$ & $8(73)$ & $89(89)$ & \\
\hline \multicolumn{4}{|l|}{ Child's sex } \\
\hline $\mathrm{F}$ & $10(48)$ & $42(41)$ & 0.64 \\
\hline M & $11(52)$ & $60(59)$ & \\
\hline \multicolumn{4}{|l|}{ Child's ethnicity } \\
\hline Polynesian & $14(74)$ & $61(71)$ & 0.56 \\
\hline Caucasian & $2(11)$ & $2(2)$ & \\
\hline Mixed/other & $3(16)$ & $23(27)$ & \\
\hline \multicolumn{4}{|l|}{ Pregnancy outcome } \\
\hline Termination of pregnancy & $10(48)$ & NA & NA \\
\hline Gestational age at termination of pregnancy, median (IQR) & $25.5(23-29)$ & NA & NA \\
\hline Live birth & $11(52)$ & $102(100)$ & NA \\
\hline Gestational age at child's birth, median (IQR) & $39(36-40)$ & $39(38-40)$ & 0.23 \\
\hline Term, $\geq 37$ weeks & $8(73)$ & $85(83)$ & \\
\hline Premature, $27-36$ weeks & $3(27)$ & $17(17)$ & \\
\hline \multicolumn{4}{|l|}{ Mother's past infection with dengue viruses } \\
\hline DENV-1 seropositivity & $17(81)$ & $88(87)$ & 0.50 \\
\hline DENV-2 seropositivity & $12(57)$ & $50(50)$ & 0.54 \\
\hline DENV-3 seropositivity & $16(76)$ & $78(77)$ & 0.99 \\
\hline DENV-4 seropositivity & $10(48)$ & $52(51)$ & 0.74 \\
\hline \multicolumn{4}{|l|}{ Other risk factors/confounders } \\
\hline Family history of congenital abnormalities & $6(29)$ & $24(25)$ & 0.84 \\
\hline Drug use during pregnancy $\ddagger$ & $9(45)$ & $34(33)$ & 0.23 \\
\hline Deltamethrin outdoor spraying during pregnancy & $10(48)$ & $50(51)$ & 0.73 \\
\hline $\begin{array}{l}\text { *Values are no. (\%) except as indicated. IQR, interquartile range; NA, } \mathrm{r} \\
\text { †Likelihood ratio using conditional logistic regression. } \\
\ddagger \text { Cannabis, cocaine, alcohol, or tobacco. }\end{array}$ & & & \\
\hline
\end{tabular}

coordinated approach to data sharing, surveillance, and research to establish the spectrum of CNS abnormalities attributable to CZS (29).

We found evidence that maternal Zika virus seropositivity, with or without reported Zika-like illness during pregnancy, was associated with 7-fold increased odds of congenital CNS defects. Zika virus seroprevalence in the control mothers in the study was $76 \%$, higher than the $49 \%$ prevalence detected in the general population of French Polynesia (28). Such a difference may exist because the previous Zika virus serosurvey was conducted on a representative subset of the general population, with a median age of 43 years, involving both female and male participants, whereas our study involved only pregnant women, with a median age of 28 years.
Several studies have clearly shown unequal rates of Zika virus infection in men and women, possibly as a consequence of sexual transmission of Zika virus $(30,31)$. Pregnant women may be more susceptible to Zika virus infection than nonpregnant women of the same age because of the immune tolerance induced by the pregnancy to tolerate paternal antigens (32). All the mothers of fetuses or children with microcephaly and other CNS congenital defects were seropositive, whereas $80 \%(4 / 5)$ of the mothers of newborns with brainstem dysfunction were seropositive, compared with $78 \%(18 / 23)$ of their matched controls (matched crude OR 1.05, 95\% CI 0.10-11.4). Although no association was found, this finding is inconclusive because the study had little power to perform subgroup analysis by congenital CNS defect. Excluding microcephaly, only 
Table 3. Crude and adjusted OR for congenital central nervous system abnormalities and maternal Zika virus infection status, French Polynesia, 2013-2016*

\begin{tabular}{|c|c|c|c|c|c|}
\hline Exposures & $\begin{array}{c}\text { Case-patients, } \\
\text { no. }(\%)\end{array}$ & $\begin{array}{l}\text { Controls, } \\
\text { no. }(\%)\end{array}$ & $\begin{array}{c}\text { Matched crude OR } \\
(95 \% \mathrm{Cl})\end{array}$ & $\begin{array}{l}\text { Matched adjusted OR† } \\
(95 \% \mathrm{Cl})\end{array}$ & $\begin{array}{l}\text { LRT } \\
\mathrm{p} \text { value }\end{array}$ \\
\hline Zika virus seropositivity & $20(95)$ & $78(76)$ & $6.02(0.77-47.1)$ & $7.07(0.86-58.3)$ & 0.02 \\
\hline \multicolumn{6}{|l|}{ Reported Zika virus infection } \\
\hline No infection during pregnancy $\ddagger$ & $1(5)$ & $24(24)$ & 1 & 1 & 0.04 \\
\hline Asymptomatic (timing unknown)§ & 12 (57) & $61(60)$ & $2.05(0.54-7.80)$ & $1.93(0.47-7.96)$ & \\
\hline Symptomatic during pregnancy & $8(38)$ & $17(17)$ & $6.79(1.36-33.8)$ & $7.19(1.39-37.2)$ & \\
\hline
\end{tabular}

*LRT, likelihood ratio test; NA, not applicable; OR, odds ratio.

†Adjusted for maternal socioeconomic status.

†Seronegative mothers and seropositive mothers who reported Zika-like illness outside pregnancy.

§Seropositive mothers who did not report Zika-like illness during or outside pregnancy.

ISeropositive mothers who reported Zika-like illness during pregnancy.

multicountry studies or meta-analyses can give a clear answer on the causal link between Zika virus and each reported rare CNS congenital defect $(33,34)$.

Within the nested cross-sectional study, we assessed control children only on anthropometry and ECD. Both eye and hearing abnormalities have been described in children with CZS; we were unable to test for such abnormalities and cannot infer any conclusion about their burden among children born without diagnosed birth defects in French Polynesia (35-37).

Our cross-sectional study did not provide evidence that maternal Zika virus seropositivity or symptomatic Zika virus infection during pregnancy were associated with unusual developmental delay in children born without birth defects (Table 4; online Technical Appendix Table 4).
Known risk factors for developmental delay (low maternal socioeconomic status and lack of breast-feeding) were associated with abnormal childhood development in this study. This result supports the validity of our findings and suggests that if reported Zika virus infection was frequently associated with delayed ECD, we would have likely detected it. However, this study lacked power to detect rare outcomes or minor developmental differences: only 17 control mothers had clear evidence of Zika virus infection with symptoms during pregnancy.

The difference in the cognitive development score in children in French Polynesia compared with children in Canada (online Technical Appendix Table 2) is likely to be the result of confounding factors such as socioeconomic status or other population differences; for

Table 4. Crude and adjusted odds ratios for maternal Zika virus infection and other risk factors and early childhood development, French Polynesia, 2013-2016*

\begin{tabular}{|c|c|c|c|c|c|}
\hline \multirow[b]{3}{*}{ Risk factors } & \multicolumn{5}{|c|}{ Early childhood development } \\
\hline & \multirow{2}{*}{$\begin{array}{c}\text { Adequate in } \\
\text { all domains, } \\
\text { no. }(\%)\end{array}$} & \multirow{2}{*}{$\begin{array}{c}\text { Question or } \\
\text { problem in } \geq 1 \\
\text { domain, no. }(\%)\end{array}$} & \multicolumn{3}{|c|}{$\begin{array}{l}\text { Adequate in all domains versus question or problem } \\
\qquad \text { in } \geq 1 \text { domain }\end{array}$} \\
\hline & & & $\begin{array}{c}\text { Crude OR } \\
(95 \% \mathrm{Cl}) \\
\end{array}$ & $\begin{array}{l}\text { Adjusted OR } \\
(95 \% \mathrm{Cl})\end{array}$ & $\begin{array}{l}\text { LRT } \\
\text { p value }\end{array}$ \\
\hline \multicolumn{6}{|l|}{ Zika virus seropositivity, $n=107$} \\
\hline No & $13(50)$ & $13(50)$ & 1 & 1 & 0.07 \\
\hline Yes & $46(57)$ & $35(43)$ & $0.76(0.31-1.84)$ & $0.35(0.11-1.13) \dagger$ & \\
\hline \multicolumn{6}{|l|}{ Reported Zika infection, $n=107$} \\
\hline No infection during pregnancy $\ddagger$ & $19(56)$ & $15(44)$ & 1 & 1 & 0.19 \\
\hline Asymptomatic, timing unknown§ & $30(54)$ & $26(46)$ & $1.09(0.47-2.59)$ & $0.51(0.16-1.58) \dagger$ & \\
\hline Symptomatic during pregnancy & $10(59)$ & $7(41)$ & $0.89(0.27-2.88)$ & $0.58(0.14-2.51) \dagger$ & \\
\hline \multicolumn{6}{|c|}{ Deltamethrin outdoor spraying during pregnancy, $n=104$} \\
\hline No & $34(69)$ & $15(31)$ & 1 & 1 & 0.07 \\
\hline Yes & $24(44)$ & $31(56)$ & $2.92(1.30-6.57)$ & 2.69 (0.92-7.84)\# & \\
\hline \multicolumn{6}{|c|}{ Maternal socioeconomic status, ${ }^{* \star} \mathrm{n}=106$} \\
\hline Middle and high & $47(66)$ & $24(34)$ & 1 & 1 & $<0.001$ \\
\hline Low & $11(31)$ & $24(69)$ & $4.27(1.80-10.2)$ & $5.28(1.96-14.2) \dagger \dagger$ & \\
\hline \multicolumn{6}{|l|}{ Breast-feeding, ${ }^{* *} \mathrm{n}=106$} \\
\hline Yes, including artificial feeding & $52(57)$ & $39(43)$ & 1 & 1 & 0.03 \\
\hline No & $6(40)$ & $9(60)$ & $2.00(0.66-6.09)$ & $4.00(1.06-15.1) \neq \ddagger$ & \\
\hline
\end{tabular}

*LRT, likelihood ratio test; OR, odds ratio.

†Adjusted for deltamethrin outdoor spraying during pregnancy, maternal socioeconomic status, breastfeeding, and date of pregnancy start (divided into 4 categories based on risk of exposure to Zika virus; see Table 2).

†Seronegative mothers and seropositive mothers who reported Zika-like illness outside pregnancy.

§Seropositive mothers who did not report Zika-like illness during or outside pregnancy.

ISeropositive mothers who reported Zika-like illness during pregnancy.

\#Adjusted for ZIKV seropositivity (main exposure), maternal socioeconomic status, breastfeeding, and date of pregnancy start.

${ }^{* *}$ No interaction (test for interaction $p=0.26$ ) and no multicolinearity were detected for maternal socioeconomic status and breastfeeding.

††Adjusted for ZIKV seropositivity (main exposure), deltamethrin outdoor spraying during pregnancy, breastfeeding, and date of pregnancy start.

¥Adjusted for ZIKV seropositivity (main exposure), deltamethrin outdoor spraying during pregnancy, maternal socioeconomic status, and date of

pregnancy start. 
example, the cognitive scale include items that may be influenced by the cultural context. Furthermore, children in Canada were recruited in Quebec's public network of kindergartens, which have programs to stimulate children's development.

The main limitation of our study is the low number of cases $(n=21)$, which makes the study underpowered to detect a strong association between maternal Zika virus seropositivity and birth defects, as illustrated by the $95 \% \mathrm{CI}$ crossing the null value. Another limitation is how the exposure was assessed. We used maternal Zika virus seropositivity as a proxy for Zika virus infection during pregnancy, but it is probable that some women were infected with Zika virus outside the gestational period. However, misclassification of mothers, which is likely to be nondifferential assuming they were infected during pregnancy when, in fact, they were infected outside the gestational period, would weaken any association between fetal CNS abnormalities and Zika virus seroconversion. We adjusted for the rapid variations in exposure over a short time by matching controls to cases by date of conception.

Our second measure of exposure, reported Zika virus infection, includes a rough estimate of time of infection (outside or during pregnancy), based on serology data combined with recalled information. This measure may be susceptible to recall bias, because mothers of case-patients are more likely to recall Zika-like illness during pregnancy. However, serology data were compatible with recalled information for both cases and controls (only 1 of 26 mothers who reported Zika-like illness during pregnancy was seronegative). Because of the geographic spread of French Polynesia and the lack of funding, controls could not be residents of any island other than Tahiti or Moorea, which contain $>70 \%$ of the overall population. We also excluded private hospitals, where $40 \%$ of deliveries occur. Therefore, it is likely that socioeconomic status confounded the associations, which is why we adjusted for maternal socioeconomic status in the analysis.

Our study confirms the association between maternal Zika virus infection and CNS congenital defects. Among children with no known congenital defects, we found no evidence that congenital Zika virus infection had a major negative effect on the early stages of childhood development. Because the first large Zika virus outbreak occurred in French Polynesia about 2 years before the Zika outbreaks in Latin America, children exposed to Zika in utero in French Polynesia are now older than those in other countries, but it may still be early to detect subtle developmental delays. Although our data are encouraging, systematic in-depth assessment of childhood development in larger cohorts of exposed children, and at older ages, is needed to detect potential developmental and learning delays.

\section{Acknowledgments}

We thank Arnaud Fontanet for stimulating discussions and for critical review of the statistical analyses. We thank Guylaine Aurili, Nathalie Guerin, Ethel Taurua, Priscillia Bompard, Poerava Chapman, and Ludivine Marcelis for help collecting the data; Marie-Françoise Merlenghi and the Centre d'Action Médico-Sociale Précoce (CAMSP) for help in the choice of the ECD assessment tool and for pediatric evaluation of children with suspected delayed development; and Laura El-Hachem for providing training on the ECD assessment tool. We also thank François Laudon, Laure Yen Kai Sun, Jean-Marc Ségalin, Evelyne Lecalvez, and Sylvie Rolland for logistics support. We thank Patrick Drury, Aneta Dujanovic, and the Global Outbreak Alert and Response Network (GOARN), as well as the World Health Organization Western Pacific Regional Office, for supervision and financial support. We thank Caroline Fuhrer and Rocio Escobar for generating the map.

\section{About the Author}

Dr. Subissi is a microbiologist and epidemiologist with a strong interest in epidemic-prone RNA viruses. He has worked as WHO consultant for the World Health Organization in epidemic contexts such as Ebola in Guinea, yellow fever in Angola, and Zika in French overseas territories.

\section{References}

1. Dick GWA, Kitchen SF, Haddow AJ. Zika virus. I. Isolations and serological specificity. Trans R Soc Trop Med Hyg. 1952;46:509-20. http://dx.doi.org/10.1016/ 0035-9203(52)90042-4

2. Baud D, Gubler DJ, Schaub B, Lanteri MC, Musso D. An update on Zika virus infection. Lancet. 2017;390:2099-109. http://dx.doi.org/10.1016/S0140-6736(17)31450-2

3. Duffy MR, Chen T-H, Hancock WT, Powers AM, Kool JL, Lanciotti RS, et al. Zika virus outbreak on Yap Island, Federated States of Micronesia. N Engl J Med. 2009;360:2536-43. http://dx.doi.org/10.1056/NEJMoa0805715

4. Cao-Lormeau V-M, Roche C, Teissier A, Robin E, Berry A-L, Mallet H-P, et al. Zika virus, French Polynesia, South Pacific, 2013. Emerg Infect Dis. 2014;20:1060. http://dx.doi.org/10.3201/ eid2011.141380

5. Musso D, Bossin H, Mallet HP, Besnard M, Broult J, Baudouin L, et al. Zika virus in French Polynesia 2013-14: anatomy of a completed outbreak. Lancet Infect Dis. 2018;18:e172-82. http://dx.doi.org/10.1016/S1473-3099(17)30446-2

6. Musso D, Cao-Lormeau VM, Gubler DJ. Zika virus: following the path of dengue and chikungunya? Lancet. 2015;386:243-4. http://dx.doi.org/10.1016/S0140-6736(15)61273-9

7. Faria NR, Quick J, Claro IM, Thézé J, de Jesus JG, Giovanetti M, et al. Establishment and cryptic transmission of Zika virus in Brazil and the Americas. Nature. 2017;546:406-10. http://dx.doi.org/ 10.1038 /nature22401

8. Tang H, Hammack C, Ogden SC, Wen Z, Qian X, Li Y, et al. Zika virus infects human cortical neural progenitors and attenuates their growth. Cell Stem Cell. 2016;18:587-90. http://dx.doi.org/10.1016/j.stem.2016.02.016

9. Cao-Lormeau V-M, Blake A, Mons S, Lastère S, Roche C, Vanhomwegen J, et al. Guillain-Barré syndrome outbreak associated with Zika virus infection in French Polynesia: 
a case-control study. Lancet. 2016;387:1531-9. http://dx.doi.org/ 10.1016/S0140-6736(16)00562-6

10. Schuler-Faccini L, Ribeiro EM, Feitosa IML, Horovitz DDG, Cavalcanti DP, Pessoa A, et al.; Brazilian Medical Genetics Society-Zika Embryopathy Task Force. Possible association between Zika virus infection and microcephaly_Brazil, 2015. MMWR Morb Mortal Wkly Rep. 2016;65:59-62. http://dx.doi.org/10.15585/mmwr.mm6503e2

11. de Araújo TVB, Ximenes RAA, Miranda-Filho DB, Souza WV, Montarroyos UR, de Melo APL, et al.; investigators from the Microcephaly Epidemic Research Group; Brazilian Ministry of Health; Pan American Health Organization; Instituto de Medicina Integral Professor Fernando Figueira; State Health Department of Pernambuco. Association between microcephaly, Zika virus infection, and other risk factors in Brazil: final report of a case-control study. Lancet Infect Dis. 2018;18:328-36. http://dx.doi.org/10.1016/S1473-3099(17)30727-2

12. Cauchemez S, Besnard M, Bompard P, Dub T, Guillemette-Artur P, Eyrolle-Guignot D, et al. Association between Zika virus and microcephaly in French Polynesia, 2013-15: a retrospective study. Lancet. 2016;387:2125-32. http://dx.doi.org/10.1016/ S0140-6736(16)00651-6

13. Rasmussen SA, Jamieson DJ, Honein MA, Petersen LR. Zika virus and birth defects - reviewing the evidence for causality. N Engl J Med. 2016;374:1981-7. http://dx.doi.org/10.1056/NEJMsr1604338

14. Honein MA, Dawson AL, Petersen EE, Jones AM, Lee EH, Yazdy MM, et al.; US Zika Pregnancy Registry Collaboration. Birth defects among fetuses and infants of US women with evidence of possible Zika virus infection during pregnancy. JAMA. 2017;317:59-68. http://dx.doi.org/10.1001/jama.2016.19006

15. Parra B, Lizarazo J, Jiménez-Arango JA, Zea-Vera AF, González-Manrique G, Vargas J, et al. Guillain-Barré syndrome associated with Zika virus infection in Colombia. N Engl J Med. 2016;375:1513-23. http://dx.doi.org/10.1056/NEJMoa1605564

16. World Health Organization. Zika situation report. 2017 [cited 2018 Mar 28]. http://www.who.int/emergencies/zika-virus/ situation-report/10-march-2017/en/

17. Besnard M, Eyrolle-Guignot D, Guillemette-Artur P, Lastère $S$, Bost-Bezeaud F, Marcelis L, et al. Congenital cerebral malformations and dysfunction in fetuses and newborns following the 2013 to 2014 Zika virus epidemic in French Polynesia. Euro Surveill. 2016;21:30181. http://dx.doi.org/10.2807/1560-7917. ES.2016.21.13.30181

18. Brasil P, Pereira JP Jr, Moreira ME, Ribeiro Nogueira RM, Damasceno L, Wakimoto M, et al. Zika virus infection in pregnant women in Rio de Janeiro. N Engl J Med. 2016;375:2321-34. http://dx.doi.org/10.1056/NEJMoa1602412

19. Schwartz DA. The origins and emergence of Zika virus, the newest TORCH infection: what's old is new again. Arch Pathol Lab Med. 2017;141:18-25. http://dx.doi.org/10.5858/arpa.2016-0429-ED

20. Moore CA, Staples JE, Dobyns WB, Pessoa A, Ventura CV, Fonseca EB, et al. Characterizing the pattern of anomalies in congenital Zika syndrome for pediatric clinicians. JAMA Pediatr. 2017;171:288-95. http://dx.doi.org/10.1001/ jamapediatrics.2016.3982

21. Kapogiannis BG, Chakhtoura N, Hazra R, Spong CY. Bridging knowledge gaps to understand how Zika virus exposure and infection affect child development. JAMA Pediatr. 2017;171: 478-85. http://dx.doi.org/10.1001/jamapediatrics.2017.0002

22. Hollingshead AB. Four factor index of social status. New Haven (CT, USA): Yale University Department of Psychology; 1975

23. Aubry M, Teissier A, Huart M, Merceron S, Vanhomwegen J, Mapotoeke M, et al. Seroprevalence of dengue and chikungunya virus antibodies, French Polynesia, 2014-2015. Emerg Infect Dis. 2018;24:558-61. http://dx.doi.org/10.3201/eid2403.171149
24. Aubry M, Richard V, Green J, Broult J, Musso D. Inactivation of Zika virus in plasma with amotosalen and ultraviolet A illumination. Transfusion. 2016;56:33-40. http://dx.doi.org/ 10.1111/trf.13271

25. de Onis M, Garza C, Victora CG, Onyango AW, Frongillo EA, Martines J. The WHO Multicentre Growth Reference Study: planning, study design, and methodology. Food Nutr Bull. 2004; 25(Suppl):S15-26. http://dx.doi. org/10.1177/15648265040251S103

26. Cheikh Ismail L, Knight HE, Bhutta Z, Chumlea WC; International Fetal and Newborn Growth Consortium for the 21st Century. Anthropometric protocols for the construction of new international fetal and newborn growth standards: the INTERGROWTH-21st Project. BJOG. 2013;120(Suppl 2):42-7. http://dx.doi.org/10.1111/1471-0528.12125

27. Bayley N. Bayley scales of infant and toddler development, 3rd edition. London: Pearson; 2005. $<$ /bok $>$

28 Aubry M, Teissier A, Huart M, Merceron S, Vanhomwegen J, Roche C, et al. Zika virus seroprevalence, French Polynesia, 2014-2015. Emerg Infect Dis. 2017;23:669-72. http://dx.doi.org/10.3201/eid2304.161549

29. Costello A, Dua T, Duran P, Gülmezoglu M, Oladapo OT, Perea W, et al. Defining the syndrome associated with congenital Zika virus infection. Bull World Health Organ. 2016;94:406-406A. http://dx.doi.org/10.2471/BLT.16.176990

30. Coelho FC, Durovni B, Saraceni V, Lemos C, Codeco CT, Camargo S, et al. Higher incidence of Zika in adult women than adult men in Rio de Janeiro suggests a significant contribution of sexual transmission from men to women. Int J Infect Dis. 2016;51:128-32. http://dx.doi.org/10.1016/j.ijid.2016.08.023

31. Lozier M, Adams L, Febo MF, Torres-Aponte J, Bello-Pagan M, Ryff KR, et al. Incidence of Zika virus disease by age and sexPuerto Rico, November 1, 2015-October 20, 2016. MMWR Morb Mortal Wkly Rep. 2016;65:1219-23. http://dx.doi.org/10.15585/ mmwr.mm6544a4

32. King NJC, Teixeira MM, Mahalingam S. Zika virus: mechanisms of infection during pregnancy. Trends Microbiol. 2017;25:701-2. http://dx.doi.org/10.1016/j.tim.2017.05.005

33. Baud D, Gérardin P, Merriam A, Alves MP, Musso D, Genton B, et al. Harness shared data in international Zika registry. BMJ. 2016;355:i5319. http://dx.doi.org/10.1136/bmj.i5319

34. Panchaud A, Vouga M, Musso D, Baud D. An international registry for women exposed to Zika virus during pregnancy: time for answers. Lancet Infect Dis. 2016;16:995-6. http://dx.doi.org/ 10.1016/S1473-3099(16)30255-9

35. Ventura CV, Maia M, Travassos SB, Martins TT, Patriota F, Nunes ME, et al. Risk factors associated with the ophthalmoscopic findings identified in infants with presumed Zika virus congenital infection. JAMA Ophthalmol. 2016;134:912-8. http://dx.doi.org/ 10.1001/jamaophthalmol.2016.1784

36. Leal MC, Muniz LF, Ferreira TSA, Santos CM, Almeida LC, Van Der Linden V, et al. Hearing loss in infants with microcephaly and evidence of congenital Zika virus infection-Brazil, November 2015-May 2016. MMWR Morb Mortal Wkly Rep. 2016;65:917-9. http://dx.doi.org/10.15585/mmwr.mm6534e3

37. de Paula Freitas B, de Oliveira Dias JR, Prazeres J, Sacramento GA, Ko AI, Maia M, et al. Ocular findings in infants with microcephaly associated with presumed Zika virus congenital infection in Salvador, Brazil. JAMA Ophthalmol. 2016;134:529-35. http://dx.doi.org/10.1001/jamaophthalmol.2016.0267

Address for correspondence: Marine Giard, Bureau de Veille Sanitaire, Direction de la Santé, BP 611, 98713 Papeete, French Polynesia; email: marine.giard@sante.gov.pf 